\title{
Research on the function Mechanism of Patent Information in the Patent Operation of Enterprises in China
}

\author{
Zhi Liping ${ }^{1} \&$ Shi Bingqi ${ }^{2}$ \\ ${ }^{1} \mathrm{Ph}$. D of School of Computer Science \& Information Engineering, Anyang Normal University, Anyang, China \\ ${ }^{2}$ M.A student of Anyang Normal University, Anyang, China \\ Correspondence: Zhi Liping, School of Computer Science \& Information Engineering, Anyang Normal University, \\ Anyang, China. Tel: 1-350-372-8754. E-mail: zhiliping1216@163.com
}

Received: May 29, 2018; Accepted: June 17, 2018; Published: June 23, 2018

The research is financed by the Henan Philosophy and Social Science Project (No. 2015CZHO04) \& the Training Scheme for Young Key Teachers in Universities of Henan (No. 2016GGJS-123) \& the Key Project of Science and Technology Research of Education Department of Henan (No. 16A520040) \& the Humanities and Social Science Project of Education Department of Henan (No. 2017-ZDJH-002) \& the Soft Science of Intellectual Property Rights of Henan (No. 20170106026).

\begin{abstract}
Patent operation, as a key activity of technological innovation and industrial transformation, is becoming increasingly important to economic development. On the basis of field investigation, a questionnaire is designed to investigate the application of patent information in the patent operation of Chinese enterprises. It is found that the biggest difficulty of Chinese enterprises is still lack of perfect patent database and patent information talents. Furthermore, the positive feedback mechanism between patent information and enterprise patent operation is analyzed, which is of great theoretical significance to our government and enterprises.
\end{abstract}

Keywords: patent information, patent operation, enterprise, positive feedback mechanism

\section{Introduction}

With the deepening development of the global knowledge economy, the business model of realizing the value of patent in the world is constantly emerging. In addition to patent transfer, licensing, standardization and patent pool, patent securitization, patent pledge loan, patent trust auction, patent insurance and other emerging patent operation are developing rapidly, and the realization of enterprise patent value is becoming more and more obvious.

As the main body of innovation, enterprises play an important role in the patent operation of our country, so how about the patent operation of the enterprises in China? How about the application of patent information in patent operation? What is the internal connection between patent operation and patent information and how does them interact? In order to solve these answers, we designed a questionnaire, analyzed the internal relationship between them, and finally put forward coping strategies.

\section{Research and Analysis of the Euestionnaire}

The patent operation in our country is in its infancy at present, so questionnaires have been distributed to the national patent operation pilot enterprises (mainly 30 production enterprises) and some well-known enterprises, and 16 valid questionnaires have been collected. Details are as follows: Sichuan Changhong Electric Appliance Co., Ltd., Baidu online Network Technology (Beijing) Co., BYD Co., Xiaomi Technology Co., Telecommunications Science and Technology Research Institute, Sany Group Co., Southwest Chemical Research and Design Institute Co., New Aut (Beijing) Video Technology Co., Zhonglian heavy Technology Co., Zhejiang Zhengtai Electric Co., Zhejiang Haizheng Pharmaceutical Co., Zhongguang Nuclear Engineering Co., Chongqing Runze Pharmaceutical Co., Fuyao Glass Industry Group Co., China Aerospace Science and Technology Group Co., Huawei Technologies Co.

By statistical analysis, the following conclusions are drawn: nine enterprises are chinese patent operation pilot projects, representing the overall development level of enterprises in our country at present; one enterprise plan declaration; fifteen institutions believe that the establishment of a sound or more perfect patent operation system; 
fourteen institutions have established a standardized patent operation process; These show that our enterprises have a certain core competitiveness.

Following, it is analyzed from the situation of patent application, patent authorization, patent operation, and patent information utilization in patent operation and so on.

\subsection{Status of Patent Applications and Authorizations}

\section{1) Status of Chinese Patent Applications and Authorizations}

The chinese patent applications and authorizations of these sixteen companies are calculated that the average number of patent applications and the number of patents granted are respectively 8101.56 and 4377.44 . As a patent application leader, Huawei Technology Co., Ltd. is far ahead in patent applications and licensing. The number of patents has laid the foundation for the operation of the patent.

\section{2) Patent Applications and Authorizations Worldwide}

It is calculated that the average number of patent applications and authorizations worldwide of these sixteen enterprises are 3914.69 and 887.63, respectively. The top four are Byd Co., the Telecommunications science and Technology Research Institute, and Millet technology Co. As the patent application leader, the number of patent applications and authorizations worldwide of Huawei Technology Co., Ltd. is also far ahead and improved the average; excluding its foreign patent applications, the average number of patent applications and authorizations worldwide dropped to 584.47 and 126.6 respectively. It shows that most enterprises in China have relatively few foreign patent reserves, which will affect their patent layout abroad.

\subsection{Application of Patent Information}

1) Sixteen enterprises have set up patent information utilization system, and most of them (68.75\%) have set up perfect patent information system. This shows that enterprises as the main innovation, patent operation activities have paid great attention to the use of patent information.

2) Free search sites that companies often use include the National Bureau website, the European Bureau, the United States Bureau and Soopat. It can be seen that $87.5 \%$ of enterprises use the website of the State Bureau to search for patents in China, while $87.5 \%$ use the European Bureau to search foreign patents. It is worth mentioning that Soopat is the most frequently used unofficial website because of its simple interface, fast retrieval and many other advantages.

3) Compared with free search websites, commercial databases are less used. Among them, $43.75 \%$ of enterprises use intellectual property publishing house or $31.25 \%$ of enterprises use British Derwent, and the probability of using other databases is very low, less than $20 \%$.

4) In the application of patent information, almost all enterprises will use patent retrieval, patent infringement risk analysis, patent legal status query. $93.75 \%$ of the enterprises will carry out the specific domain / industry patent analysis, $87.5 \%$ of the enterprises will carry out the invalid patent inquiry, the product export country patent risk analysis, the patent early warning, $62.5 \%$ of the enterprises will carry on the patent trend research and the technology development trend patent navigation.

\subsection{Status of Patent Operations}

The results show that the main ways for enterprises to deal with patent are self-industrialization, cooperative transformation with other enterprises and licensing of others, and patent technology license, transfer and industrialization are the main mode of patent operation, among which transfer and license mainly take place within the enterprise.

\subsection{Difficulties and Needs in Patent Information Application and Patent Operation}

Of the sixteen enterprises, ten of them lack the patent information application talents, eight lack of patent data resources, six do not know how to apply the patent information in the patent operation.

The statistical results show that enterprises most hope that the state will increase their support to local authorities, followed by providing a free patent analysis system, strengthening the training of patent information personnel, and establishing a perfect patent information service platform. Provides multi-level patent retrieval guidance and training.

The difficulties and problems encountered by enterprises in patent operation, mainly lack of practical talents of patent information, followed by asymmetry of supply and demand information in patent operation, and lack of patent database. 
From the above three investigation problems, it can be seen that enterprises take patent information practical talents as the main difficulty in patent information or patent operation, which indicates that our country should still take the cultivation of patent information application talents as the main task in the future.

\section{The Action Mechanism of Patent Operation and Patent Information}

Through the analysis of the questionnaire, we find out the current situation of patent information application in the patent operation of Chinese enterprises. At the same time, it is not difficult to find the relationship between patent operation and patent information. Patent information is the basis of enterprise patent operation, which provides an effective support for patent operation. The further development of patent operation promotes the prosperity of patent information, and the relationship between them conforms to the positive feedback mechanism.

\subsection{Positive Feedback Mechanism}

The feedback is divided into positive feedback and negative feedback. It refers to the return of information to the output, which has a certain impact and effect.

Positive feedback is a form of feedback, it means that the function of feedback information is the same as that of control information. The main function of positive feedback in patent operation and patent information application is to amplify the small changes so as to promote the patent operation of enterprises in a stable state.

The positive feedback mechanism refers to the interaction between objects. There is a force that encourages each other. It will strengthen and amplify the original development trend and form the inevitability that cannot be reversed. Therefore, the positive feedback mechanism means that the stronger can be strengthened. If an enterprise wants to maximize its benefits through patent operations and the use of patent information, it can promote its own patent operation level by making a series of systems and measures with positive feedback mechanism, so that it has a place in the field of patent.

\subsection{The Relationship between Patent Operation and Patent Information based on Positive Feedback Mechanism}

By analyzing the questionnaire, we can see that the patent operation and the application of patent information are in line with the positive feedback mechanism. The enterprises with successful patent operation also have strong ability to use patent information and grasp the patent very well. The proper use of patent information, to a large extent, has promoted the deepening development of the patent operation of enterprises. The perfect combination of the two is that the enterprise can fully realize its own benefit maximization. Of course, the use of positive feedback will also make enterprises more powerful in patent operation and patent information use. This problem cannot be ignored in our drive to deepen the development of patent operation.

The patent operation of enterprises cannot be separated from the support of patent information. Its different links to the patent information demand each has the emphasis, also has its own unique demand. The deepening development of patent information is inseparable from the promotion of patent operation. Therefore, the foundation of patent operation is the technical scheme as the content of patent entity, which can be understood as technical information of patent. The validity of the patent right, on the other hand, is the guarantee of the patent operation, and it forms the legal information of the patent. Patent and its patented products in the market performance, the formation of patent market information. From the perspective of patent information,patent operation is a comprehensive application of technical information, legal information and market information of patents by means of finance, market and law. In this sense, patent operation is equivalent to the application of patent information. Convenient, fast and effective application of patent information is the key to the success of patent operation.

Therefore, if an enterprise wants to have its own advantages in the era of deepening the development of global knowledge economy, it should actively focus on patent operation and the use of patent information, so that it has its own competitive advantage in the market.

\section{Countermeasures of Patent Information Application and Promotion in Patent Operation of Enterprises}

\subsection{Improving the Consciousness and Ability of Patent Information Application in Enterprises}

In order to improve the awareness of the use of patent information in enterprises, we should start at the root. Actively building enterprise patent information culture to make it popular among the people. To actively create an enterprise environment for patent operation, management and staff can be regularly trained about patent operations and patent information. Develop the characteristic patent information training and mobilize the various departments of the enterprise according to the industry superiority of the enterprise itself. Build a good patent information application platform in the enterprise. 


\subsection{Strengthening the Cultivation of Professional Talents}

In order to meet the needs of government agencies, enterprises and institutions for patent information talents, the government should further strengthen the selection and training of patent information practical talents. Although the State Administration has selected four groups of patent information teachers and leaders, it has played a positive role in training patent information talents. However, after being selected, most of these talents are idle. It has not been fully utilized by provincial and Municipal Bureau and played their role. It is suggested that the National Bureau set up a talent management file for patent information talents (teachers and leading talents). By the local bureau (provincial and municipal) joint training, give them teaching, training opportunities, so that they can exercise, really play a role.

\subsection{Perfecting the Construction of Patent Information System}

If an enterprise wants to make full use of patent information to create market value for itself, it must constantly optimize and perfect its patent information application system to ensure the efficient operation of the enterprise. It is suggested that enterprises should build a unique system of sharing patent information achievements, a patent information training system, for example, develop different and patent information training for different levels of employees to improve their business ability.

\subsection{Strengthen the Communication of Enterprise Patent Operation}

With the integration of the world economy today, enterprises should pay more attention to cooperation so that patent information can be circulated in a wide range and increase in value, thus creating greater economic benefits for themselves. Enterprises can regularly hold some patent information exchange meetings to achieve "win-win" and "multi win".

\subsection{Speeding up the Construction of Patent Database}

At present, there are many free patent information platforms at home and abroad, such as Soopat, Innojoy, Patentics and so on. However, the free features offered by these platforms are simple and difficult to meet the needs of enterprises. But its charge function is actually expensive, each year approximately 2-3 million, the majority enterprise is difficult to pay. Therefore, the perfect patent database construction needs the government to increase the fund support, supports some conditional patent information service institutions to develop the public welfare function perfect patent information service platform. It also establishes some special databases which can be used by enterprises free of charge, so as to enhance the enthusiasm of enterprises to use patent information, thus promoting the deepening development of patent operation and patent information application in China.

\section{Conclution}

Under the background of economic globalization and knowledge economy, patent operation, as a key activity of technological innovation and industrial transformation and upgrading, is becoming increasingly important to economic development. In order to maximize the benefits of enterprises, our country should strengthen the support for patent operation and patent information, correctly understand the positive feedback relationship between the two, take measures to promote it, take both ways and grasp it with both hands. We will jointly promote the development of patent undertakings in China.

\section{References}

Hu, P., Huang, M. L., \& Zhu, X. Y. (2013). Finding Nuggets in Patent Portfolios: Core Patent Mining and Its Applications. Tsinghua Science and Technology, 18(4), 339-352. https://doi.org/10.1109/TST.2013.6574672

Tand, S. H., \& Chen, J. X. (2010). Research on Component Law of Chinese Patent Medicine for Anti-influenza and Development of New Recipes for Anti-influenza by Unsupervised Data Mining Methods. Journal of Traditional Chinese Medicine, 30(4), 288-293. https://doi.org/10.1016/S0254-6272(10)60058-1

Wang, J. C., Zhou, X. D., Hu, Y. Y., \& Zhao, Z. L. (2018). An empirical research on the field of wireless charging based on patent life length. High Technology Letters, 24(01), 95-102.

Xia, Y., Tang, L., Yao, L., Wan, B., Yang, X., \& Yu, L. (2012). Literature and patent analysis of the cloning and identification of human functional genes in China. Science China(Life Sciences), 55(03), 268-282. https://doi.org/10.1007/s11427-012-4299-6

Yuan, X. M., \& Zhang, Z. Y. (2016). Studies of world carbon fiber industry from a perspective of patent analysis. High Technology Letters, 22(3), 313-320.

Zhang, L. W., Zhang, Q., \& Zhu, D. H. (2009). Application Research of Robust LS-SVM Regression Model in Forecasting Patent Application Counts. Journal of Beijing Institute of Technology, 18(4), 497-501. 
Zhang, X., Li, Z. R., Zhao, Y. H., \& Zhou, L. J. (2013). Studies of layout of world machine tools industry based on patent analysis. High Technology Letters, 19(3), 246-253.

Zhi, L. P. (2014). Technological Development Situations of Ontology in China Based on Patentometrics. Journal of Intelligence, 33(6), 79-83.

Zhi, L. P., \& Wang, H. S. (2012). A Patent Collaborative Management Model Between High-Tech Enterprises. Science of Science and Management of S. \& T., 33(9), 113-121.

Zhi, L. P., \& Zhang, S. L. (2014). Research on Semantic Retrieval Based on Patent Ontology. Research on Library Science, 2014(7), 57-61.

\section{Copyrights}

Copyright for this article is retained by the author(s), with first publication rights granted to the journal.

This is an open-access article distributed under the terms and conditions of the Creative Commons Attribution license (http://creativecommons.org/licenses/by/4.0/). 